JOSIP GRACIN, Ph.D.

E-mail: josip.gracin@posta.hr

Cratian Post Inc.

Jurišićeva 13, HR-10000 Zagreb, Republic of Croatia

ANTUN STIPETIĆ, Ph.D.

E-mail: stipetic@fpz.hr

Faculty of Transport and Traffic Sciences

Vukelićeva 4, HR-10000 Zagreb, Republic of Croatia
Traffic Infrastructure

Preliminary Communication

Accepted: Dec. 17, 2007

Approved: Oct. 22, 2009

\title{
DESIGNING POSTAL NETWORK UNITS
}

\section{ABSTRACT}

The existing postal infrastructure cannot efficiently support the requirements of new technologies and the supply of services on the open market of postal services. Post offices do not meet the new needs, therefore requiring an adjustment to new traffic and service requirements. The functioning of the postal system in the Republic of Croatia was carried out in order to adjust the functional equipment of the system to the introduction of the new technologies and services. At the same time a requirement was set to the public postal operator for more efficient performing of the universal postal service. Based on the analyses of the postal system functioning, a modular procedure of designing the postal network units was proposed and it provides the possibility of adjustment to the new technological, organizational and safety requirements of the postal system.

\section{KEY WORDS}

postal units, module designing, postal traffic efficiency

\section{INTRODUCTION}

The design of postal facilities and network according to new service requirements, raising the level of the quality of service, affordable prices, and rationality represent the basic preconditions for successful operation of every postal operator, as an important part of the economic and total infrastructure of the Republic of Croatia.

At the time of emphasised dynamic changes, the efficiency of the postal system is questionable as well as the impossibility of satisfying the needs of a very interesting communication and distribution market. The characteristic of the network infrastructure is an excessive number of primary units and of processing units of postal items that have not been adjusted to the change of the service structure and the new technical and technological solutions.

The general legal frame for the postal services area (based on the Act on Postal Services of the Republic of Croatia [9] and the European Regulations), defines that the public operator shall ensure access to the pub- lic network and other service providers. This imposes new functional requirements in designing the conceptual solutions of the postal infrastructure.

The problem of standardisation and adjustments of the postal system infrastructure equipment and its functioning in the essentially modified technical, technological and market environment is the topic of research of infrastructure equipment of the postal system in order to stimulate the efficiency and efficacy of the system.

The postal system has been constantly developing, modernising and improving the operation process. Therefore, the system and the operation processes have to be harmonised with the new traffic and service requirements, in order to follow the trend of development and improvement in single postal network units.

The objective of this research is the design of postal units as a set of modules and creation of an architecture of standardised postal system objects. The basis for this is the modular structure of the unit. The postal unit modules are defined, the characteristics of each module are determined, and, based on the defined new traffic-service requirements a new unit architecture is created.

\section{ANALYSIS OF THE EXISTING POSTAL FACILITIES}

The analysis of the postal system units has been carried out by empirical and inductive method, and by a study in the area of ten county centres.

For the analysis, the postal network units for the processing of postal items were selected, as well as fifteen post offices each from the studied county centres (Zagreb, Osijek, Rijeka, Split, Slavonski Brod, Pazin, Gospić, Zadar, Šibenik and Dubrovnik), which realize maximal revenues during the year, i. e. those that perform the most of postal services.

The functional infrastructure equipment level of each system unit was studied. The obtained results from the questionnaire were analysed, systematised 
and evaluated, in order to obtain a total grade of the condition regarding the infrastructure equipment level of the Croatian Post system (Table 1).

Table 1 - Results of the study of infrastructure equipment of the system

\begin{tabular}{|c|c|}
\hline \multicolumn{2}{|l|}{$\begin{array}{l}\text { 1. Post office (general type of facility) status grade (1 - } \\
\text { 5) }\end{array}$} \\
\hline \multicolumn{2}{|l|}{ 1.1 Service availability: } \\
\hline - location & 4 \\
\hline \multicolumn{2}{|l|}{ - access: } \\
\hline - vehicles & 3 \\
\hline - pedestrians & 4 \\
\hline - other service providers & 2 \\
\hline \multicolumn{2}{|l|}{ 1.2 Spatiality: } \\
\hline - total area & 3 \\
\hline - users' section & 3 \\
\hline - official section & 3 \\
\hline - sufficient number of accompanying premises & 3 \\
\hline \multicolumn{2}{|l|}{ 1.3 Communication: } \\
\hline $\begin{array}{l}\text { - harmonization of technol. flows (vertical and hor- } \\
\text { izontal) }\end{array}$ & 2 \\
\hline - technological continuity of operating processes & 2 \\
\hline \multicolumn{2}{|l|}{ 1.4 Security: } \\
\hline $\begin{array}{l}\text { - physical prevention of access to object and work- } \\
\text { place }\end{array}$ & 3 \\
\hline - electronic security system & 4 \\
\hline - security cabinets - safes & 3 \\
\hline \multicolumn{2}{|l|}{ 1.5 Technical equipment: } \\
\hline - total number of built-in counters & 4 \\
\hline - number of computerized counters & 3 \\
\hline - number of background workplaces & 3 \\
\hline \multicolumn{2}{|l|}{$\begin{array}{l}\text { 2. Specialised type of facility (sorting units) status grade } \\
(1-5)\end{array}$} \\
\hline \multicolumn{2}{|l|}{ 2.1 Technical equipment: } \\
\hline - mechanised & 3 \\
\hline - automated & 4 \\
\hline - internal transport & 3 \\
\hline - access ramps & 3 \\
\hline $\begin{array}{l}\text { - adequate arrangement of machines and equip- } \\
\text { ment }\end{array}$ & 2 \\
\hline 2.2 Access for other service providers: & 2 \\
\hline \multicolumn{2}{|l|}{ 2.3 Functionality: } \\
\hline - technical & 3 \\
\hline - technological & 3 \\
\hline
\end{tabular}

\begin{tabular}{||l|l||}
\hline \multicolumn{2}{|l|}{ 2.4 Flexibility: } \\
\hline - ability to adjust to new transport requirements & 3 \\
\hline $\begin{array}{l}\text { - possibility of expansion not interfering with tech- } \\
\text { nological flows }\end{array}$ & 2 \\
\hline 2.5 Necessary areas for: & 3 \\
\hline - production equipment and passages & 2 \\
\hline $\begin{array}{l}\text { - auxiliary equipment and instruments for postal } \\
\text { item handling }\end{array}$ & 3 \\
\hline - transport areas & 2 \\
\hline - storehouses of unprocessed postal items & 2 \\
\hline - auxiliary areas & 3 \\
\hline 2.6 Satisfactory working and safety conditions & \\
\hline \hline
\end{tabular}

The analysis of the collected data from the questionnaires led to the conclusion that the current condition of the infrastructure and facilities cannot efficiently support the requirements of new technologies and the supply of new services in the environment of modified service and transport requirements. It was found that the postal network is characterized by an excessive number of postal network units for receiving and processing of postal items that are not adjusted to the change of service structure and new technical and technological solutions. Private "subcontracted" post offices are not represented at all, which places additional burden on the national operator.

The analysis of the obtained results of the carried out study has shown that the locations of the postal units (offices) and postal services partly satisfy the needs of a modern postal unit, whereas access to vehicles and other service providers is not at the required level of satisfying the users' requirements.

Spatiality is also very diverse, and the common characteristic of almost all offices is the confined space for the receiving of postal items of larger dimensions, and storage and delivery of these at post offices. In case of accompanying premises, particularly those which accommodate safety cabinets / safes, the security level regarding protection of people and material values has to be improved.

The technical security systems do exist, but they are technologically and technically obsolete.

\section{DESIGNING OF MODULAR STRUCTURE OF POSTAL NETWORK UNITS}

\subsection{Basic principles of designing technological areas}

The areas and configuration of postal facilities are determined according to the preliminary indicators of 
technical and economic analysis of the facility. The starting point for the form and size of the functionally designed infrastructure consists in the forecast technologically processes and the definition of the area for optimal realization of these processes.

The basic principle applied in designing the structural plan is to provide the shortest paths of the main technological flows. The structuring of a functional facility is harmonized with the urban environment, especially the transport environment, and the accompanying areas are located separately from the zones of the main technological flows.

\subsection{Forming the structure of postal network units}

In order to determine the optimal basic technological areas of the postal system, it is possible to set up the basic modular structure of the postal network unit, as the starting basis for all the scenarios of designing individual elements of the actual postal system.

The modular structure of the postal network units encompasses the building, the installed equipment and the personnel performing the target functions, with certain mutual relations among the system functioning, energy and information.

The functions in the system are realized according to certain principles or operation scheme. Such forms of functions and their realization in the basic (initial) structure of the postal network represent the model of the functional and schematic postal structure. The general model of this system can be presented in a metrix form.

The matrix structure (Figure 1) during operation is adjusted to the technological parameters such as:

- throughput capacity of the technical means,

- profitability (exploitation speed),

- weight and dimensions of technical means,

- reliability,

- space dimensions and similar.

In the basic structure the postal network units unify the requirements which are used to systemically connect the energy, information, traffic flows with the possibility of their synchronized action within the technological process.

The interconnection of technical equipment and the devices (machines) in the basic structure of the postal network units, and the connection with the accompanying services form the technical complex in which three forms of flows occur, these being: material flows -postal items $\left(T_{P}\right)$, energy flows $\left(E_{n}\right)$ and information flows (I).

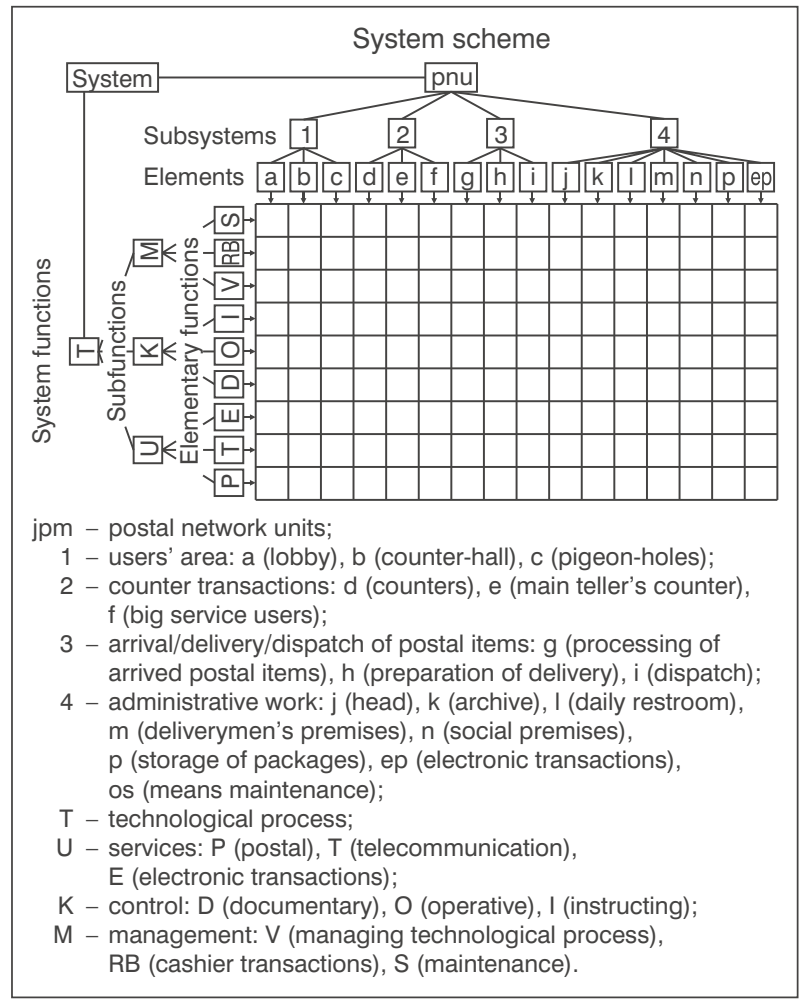

Figure 1 - Matrix presentation of the functional structure of the universal model of the postal network unit

\subsection{Setting up of the main structure of postal network units}

Based on the structure matrix (Figure 1) the function of criteria can be set in the form of the expression:

where:

$$
\min A_{\text {JPM }}=\sum_{\mathrm{i}} \sum_{\mathrm{j}} \mathbf{A}_{\mathrm{ij}} \mathbf{I}_{\mathrm{ij}} \mathbf{I}_{\mathrm{ij}}
$$

$\mathbf{A}_{\mathrm{ij}}$ - symbol (value) of the functional area in the structure and the functional-structural matrix of the postal network unit model;

$\mathbf{I}_{\mathrm{ij}}$ - volume of the movement intensity (information, communication, and documents) between premises or workplaces of constant character, which define also the interdependent activities in the structure;

$\mathbf{I}_{\mathrm{ij}}$ - length of relations (and/or distances) between the locations of the premises, sectors, workplaces and limitations imposed by the environment.

Before setting up the model, a document is set (the basic data) of quantitative and qualitative character for the real basic structure of the postal network unit, such as:

- presentations of administrative and technological parts of the unit;

- defining of areas (values, dimensions) of workplaces and departments; 
- working processes (activities for a certain process);

- determining of measures for individual activities;

- minimal distances between workplaces, departments;

- number of passages and contacts between workplaces, departments;

- documentation flow between workplaces, departments.

On the basis of the mentioned documents, the basic structure is elaborated:

- by designating the structural areas (Figure 2);

- by setting the scheme of the basic structure of the postal network unit;

- by forming the matrix scheme of the basic structure;

- by forming the interdependence matrices;

- by developing a dependence diagram between single structure departments.

Apart from the classical activities, in considering and forming the basic structure of the postal network units the possibility of performing new services (activities) is also recognized, such as: integration and processing of output flows of the hybrid post, performance of services and postal logistics management, electronic transactions, new services of monetary transactions, openness towards other service providers.

By expanding the operation through the introduction of new or the development of the existing services the additional working areas have to be planned in designing of technological areas of the standardized postal facility.

The basic structure of the postal network unit (Figure 2) is used to represent the grouped and functionally related areas which unify:

- basic areas (A, B, C, D, E, F, G, H, I, J, K, L, H, M, $\mathrm{P}, \mathrm{e})$,

- administrative and official and social areas $(\mathrm{N}, \mathrm{O}$, $\mathrm{Q}, \mathrm{R}, \mathrm{S}, \mathrm{T}, \mathrm{U}, \mathrm{U} / \mathrm{I})$.

Also, the basic flows (technological and functional) in the working process of this structure are presented. This structure is comprehensive and suitable for systemic engineering presentation of the structural analysis, modular documentation of the system and practical application. The general applicability and the transformation possibility of the basic postal unit structure are expressed through modules (blocks) of internal layout of the areas.

\subsection{Designing of technological structure}

The technological structure of the postal network unit is designed so that the areas from the basic layout of the postal system (Figure 2), which are functionally connected to a bigger department, are constructed

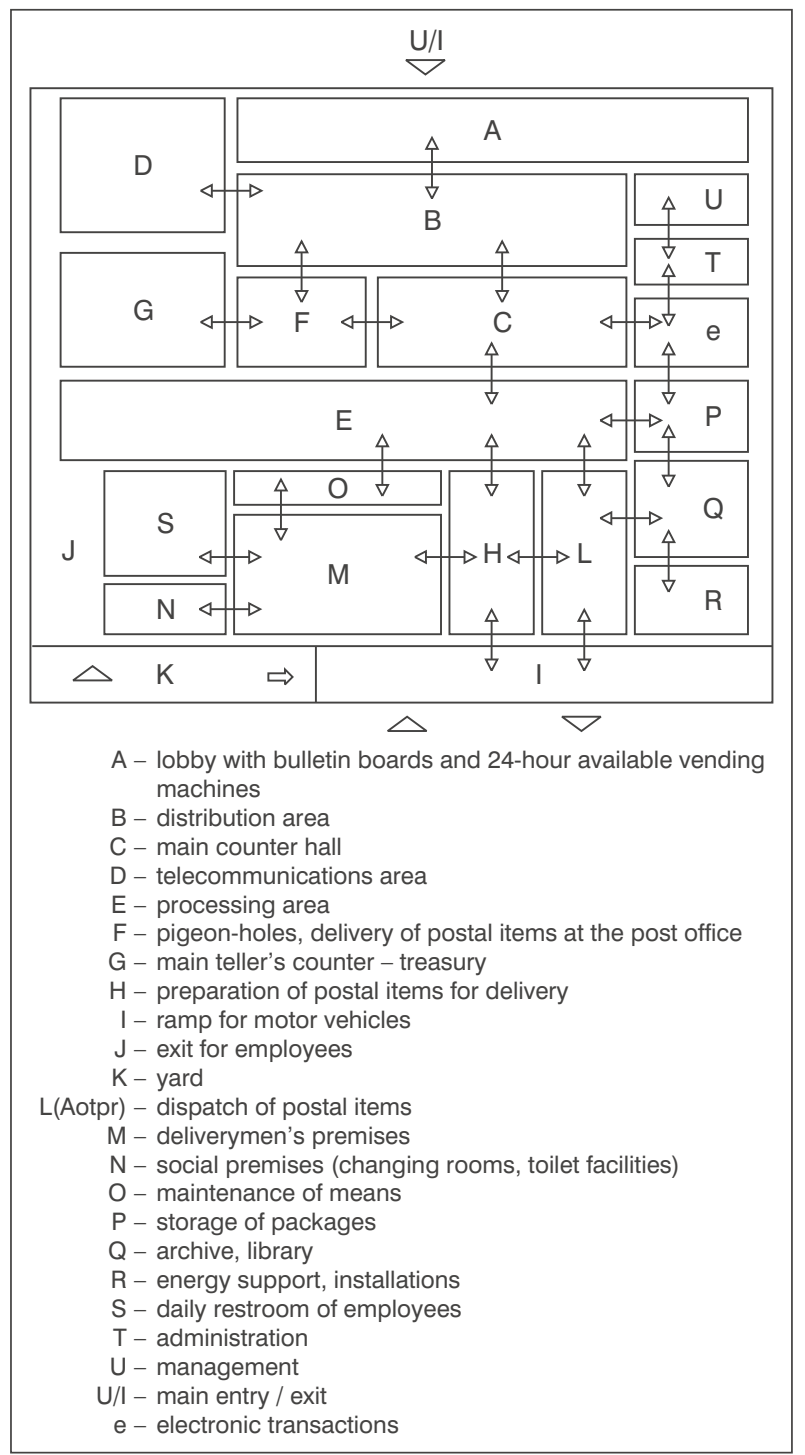

Figure 2 - Basic layout of functional postal system with the required areas and flows

jointly or close to each other, and are presented as a single area. The module areas are designated with symbols of both areas (from Figure 2) in such a way that the first major capital letter of the alphabet is used to denote a bigger area, and a smaller capital letter (in the form of a subscript) for the associated areas (Table 2).

For the presentation of the modular structure of the postal network unit, the design elements are set [5]:

- connectivity matrix of single modules (Table 2);

- interdependence matrix according to quality of connections between single modules (Fig. 3);

- diagram of flows and physical connections between single modules / departments (Figure 4).

For each denoted module the required area is calculated separately, and the traffic and service forecast is taken as the starting point. 
Table 2 - Connectivity matrix of single modules of the basic structure of the postal network unit

\begin{tabular}{|c|c|c|c|c|c|c|c|c|}
\hline Module & $\mathrm{B}_{\mathrm{D}}(1)$ & $\mathrm{C}_{\mathrm{F}}(2)$ & $\mathrm{E}_{\mathrm{O}}$ & G (4) & $\mathrm{L}(5)$ & $\mathrm{H}(6)$ & $\mathrm{M}(7)$ & $\mathrm{N}(8)$ \\
\hline $\mathrm{B}_{\mathrm{D}}(1)$ & & $\mathrm{I}_{\max }$ & & & & & & \\
\hline $\mathrm{C}_{\mathrm{F}}(2)$ & $\mathrm{I}_{\mathrm{CBmax}}$ & & $\mathrm{I}_{\max }$ & $\mathrm{I}_{\mathrm{i}}$ & & & & \\
\hline $\mathrm{E}_{\mathrm{O}}(3)$ & & $\mathrm{I}_{\max }$ & & & $\mathrm{I}_{\max }$ & & $\mathrm{I}_{\mathrm{p}}$ & $\mathrm{I}_{\mathrm{Nmin}}$ \\
\hline $\mathrm{G}(4)$ & & $\mathrm{I}_{\mathrm{i}}$ & & & & & & \\
\hline $\mathrm{L}(5)$ & & & $\mathrm{I}_{\max }$ & & & $\mathrm{I}_{\mathrm{i}}$ & $I_{\min }$ & \\
\hline $\mathrm{H}(6)$ & & & & & $\mathrm{I}_{\mathrm{i}}$ & & $\mathrm{I}_{\min }$ & \\
\hline M (7) & & & $\mathrm{I}_{\mathrm{p}}$ & & $\mathrm{I}_{\min }$ & $I_{\min }$ & & $\mathrm{I}_{\min }$ \\
\hline $\mathrm{N}(8)$ & & & $\mathrm{I}_{\min }$ & & & & $\mathrm{I}_{\min }$ & \\
\hline
\end{tabular}

By analyzing the flows between the departments and sectors of the structure of the postal network unit, the "from-to" matrix is generated. The flows that move between single departments and sectors are input into the matrix structure according to the intensity, and the quantitative symbols of flow intensity are applied, and these are input into the connectivity matrix fields:

$\mathrm{I}_{\max }-$ maximal flow,

Ii - expressed flow between structure parts,

$I_{p}-$ average (mean) flow;

$\mathrm{I}_{\mathrm{s}}$ - weaker flow;

$I_{\min }-$ minimal flow;

0 - no flow.

The flows between modules are entered into the field which is located at the intersection of the column and row of single modules (blocks).

The analysis of the flow intensity indicates three groups of departments which form a functional whole, and these are: sector of administrative transactions, sector of technological and technical activities, sector for providing services (counters).

The elaboration of the procedure of designing the modular structure of the postal network unit of eight modules (departments) is presented by Table 2 and Figures 3 and 4.

This design uses the tables for typical criteria and the interrelation reasons (Table 3) and the level of significance of the closeness between the parts of the structure and the dependence of single connections in the structure (Table 4).

For unequal influence of quantitative and qualitative factors a transition matrix is formed as a common interdependence matrix. Based on the common interdependence matrix the diagram of flows and physical connections is set up (Figure 4), which serves to form the final physical layout of the departments.

The matrix of connections of the structure modules represents a document for the interdependence matrix of structure elements activities which is formed according to the quality of connections between single elements (modules) of the basic structure of the postal network unit.

Figure 3 shows an example of forming the structure of eight modules using the area symbols from Figure 2 and Table 2. Each matrix field shows a connection of two structure elements (modules) according to the level and cause of interdependence. The fields have been divided by a broken line, the upper part of the field used to enter the symbol of interdependence significance (Table 4) and the lower part for the entry of the ordinal number of the reason for determining the given dependence (Table 3).

Table 3 - Typical criteria and reasons which affect the interrelations in the system

\begin{tabular}{|c|l||}
\hline symbol & \multicolumn{1}{|c|}{\begin{tabular}{c}
\multicolumn{1}{c|}{ description of causes and reasons } \\
for the flows
\end{tabular}} \\
\hline \hline 1 & $\begin{array}{l}\text { Level of the need for contact among the em- } \\
\text { ployees }\end{array}$ \\
\hline 2 & Level of communication \\
\hline 3 & $\begin{array}{l}\text { Engagement of the same equipment and instru- } \\
\text { ments }\end{array}$ \\
\hline 4 & $\begin{array}{l}\text { Usage of common archive and database } \\
\text { (card-file) }\end{array}$ \\
\hline 5 & $\begin{array}{l}\text { Technological flow of activities or technical } \\
\text { suitability }\end{array}$ \\
\hline 6 & $\begin{array}{l}\text { Engagement of the same personnel and their } \\
\text { cooperation }\end{array}$ \\
\hline 7 & Specific wishes of the management \\
\hline 8 & $\begin{array}{l}\text { Need to control place "k" from place “i” or vice } \\
\text { versa }\end{array}$ \\
\hline 9 & Flow of postal items and transport means \\
\hline 10 & Noise, dust, danger \\
\hline 11 & Disturbance or interruptions \\
\hline 12 & Absence of direct passages \\
\hline
\end{tabular}

The interdependence matrix of structure elements (modules) can be presented by an interdepen- 


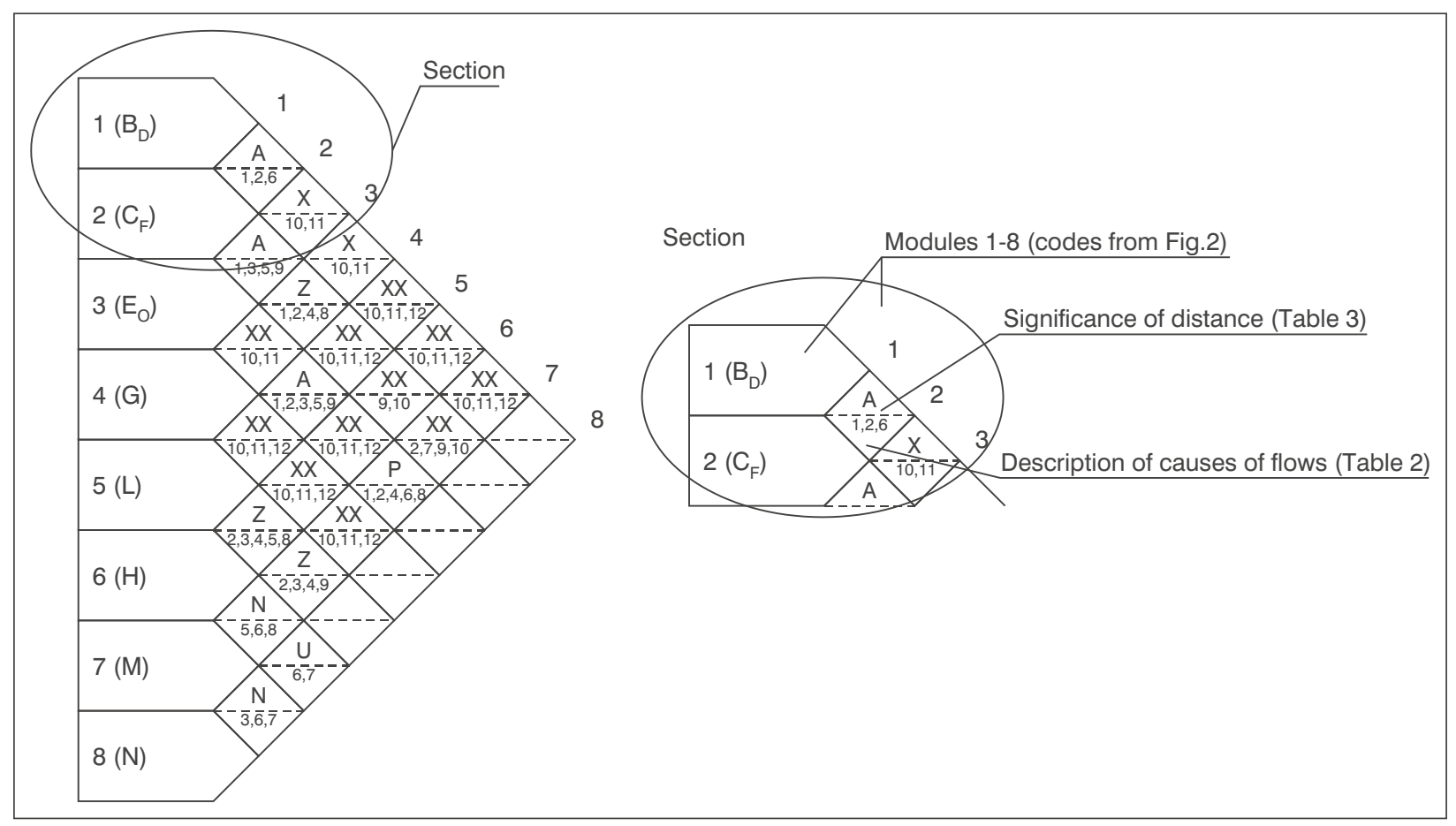

Figure 3 - Interdependence matrix of activities according to the quality of connections between modules of the postal network units.

Table 4 - Level of the distance significance between structure elements and the dependence of single structure connections

\begin{tabular}{||c|c|l||}
\hline Code & Symbol & \multicolumn{1}{|c||}{$\begin{array}{c}\text { Significance of connections } \\
\text { in the structure }\end{array}$} \\
\hline \hline A & IIII & Absolutely necessary \\
\hline $\mathrm{Z}<\mathrm{A}$ & $|I| \mid$ & Substantially necessary \\
\hline $\mathrm{P}<\mathrm{Z}$ & || $\mid$ & Necessary \\
\hline $\mathrm{U}<\mathrm{P}$ & || & Usual \\
\hline $\mathrm{N}<\mathrm{U}$ & $\mid$ & Insignificant \\
\hline $\mathrm{X}<\mathrm{N}$ & $\sim$ & Undesirable \\
\hline $\mathrm{XX}$ & $\sim$ & Prohibited \\
\hline
\end{tabular}

dence matrix (Figure 3) for the analyzed case of eight components (modules). The Figure shows that, for instance, the connection of modules $\mathrm{C}_{\mathrm{F}}$ and $\mathrm{B}_{\mathrm{D}}$ and modules $\mathrm{E}_{\mathrm{O}}$ and $\mathrm{C}_{\mathrm{F}}$ is absolutely necessary and therefore designated by the letter code A (from Table 4). The description of the causes or the reason for the existence of the flows among the single modules, for each of them separately, is presented by the ordinal number of the reason (according to Table 3 ) under the letter code of the significance level of the distance.

It should be noted that in practical solving of this model there may be different qualitative and quantitative influences for each pair of locations, which can be seen in Figure 4. The mentioned relations are

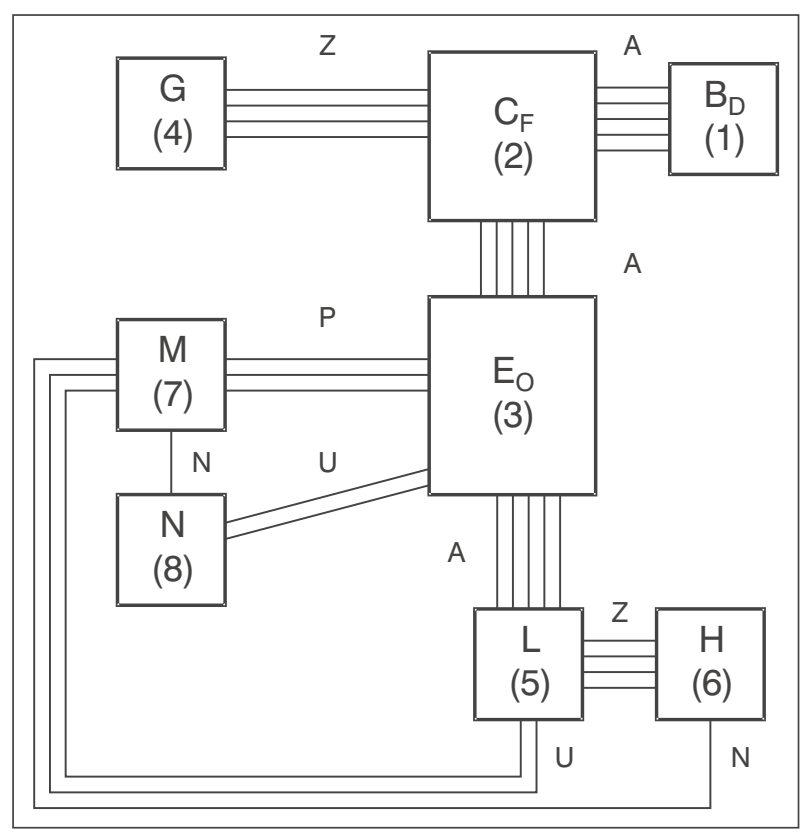

Figure 4 - Diagram of flows and physical connections (dependence diagram) between modules of postal network units

taken into consideration in generating the transition matrix.

\section{APPLICABILITY OF MODULAR DESIGN}

The universality and applicability of the modular design to solving of single actual situations of postal 
network units (jpm), is achieved in practice by the possibility of:

- adding and / or removing single structural areas (modules),

- introduction and / or removal of flows and connections required by the redesigned system of areas,

- introduction and / or removal of flows and connections required by the redesigned system.

The characteristics of the basic modular structure of the postal system enable the following scenarios:

\section{Forming of modular structure of the first-rank postal network unit}

This is achieved by adding modules for automatic processing of postal items to the initial structure (Figure 2) as well as the areas for the expansion of the administrative and social activities. Such transformation results in a modular structure of the postal network units of the highest rank, which is capable of performing all the technological processes. Such postal network units belong to the group of big post offices located at the county centres.

\section{Forming of modular structure of the second-rank postal network unit}

This is achieved by the mapping of the modular structure (Figure 2), with individual calculations of the areas of single modules based on the traffic analyses (forecasts). In practice, these postal network units represent delivery post offices.

\section{Forming of modular structure of the third-rank postal network unit}

This is achieved when the areas for the processing and preparation of postal items delivery, as well as the excess of administrative and social areas are removed from the basic modular structure (Figure 2). This transformation brings a modular approach to designing of counter postal network units, which is a much better and more practical design than the previous ones.

It can be seen that, as necessary, the postal unit structures of different ranks can be formed from the basic modular structure, retaining all the necessary technological structure relations.

The unique standardized infrastructure (distributive capacities and postal network units) is an important contribution to the development strategy of the postal traffic and services. The transformation and rational conditions of providing universal service are the precondition of long system sustainability.

Modular design of areas in the postal facilities presented in this paper enables the design of standardized units of postal networks, which is the basis of adapting the public operator by new traffic service require- ments. By analyzing the condition of infrastructure and public operator facilities, various approaches to the design and layout of areas have been determined, which, in case of many layout designs, results in difficulties in technological processes, implementation of ergonomic principles at workplaces and satisfaction of minimal safety measures of the facilities. The installation of the configuration of the technical equipment of a universal counter, for instance, is not equally possible in all the postal network units due to physical limitations. Since (unique) standardized technical equipment is purchased, according to the legal regulations, at the level of postal operator management for all the postal network units, modular design is necessary for the standardization of the technological areas as the basis to the development, efficiency and stability of the system.

\section{CONCLUSION}

Postal systems pass through a very complex process of transformation and adjustment in the conditions of global changes. For successful operation it is necessary to develop the models which take into consideration the specific characteristics of the environment, as well as make the system less expensive.

The design of postal network units, on the principle of modules has to be implemented because of the maximally rational management and improvement of infrastructure resources, since they simplify the construction and reduce the expenses.

The suggested model is a good basis for producing the technical documentation of postal units of modular type. The model presents the basic approach principles to modular design of postal network units of general and specialized type (post offices and postal centres) adjusted to specific requirements and capabilities of integration into the existing postal network structure.

The contribution of the model is in the new approach to the production of technical documentation for the construction of new or reconstruction of the existing postal network units which includes all the necessary adjustments of the infrastructure equipment level of the module. Using the software tools this model allows practical implementation in the functional shift of the postal network unit and defining of the technical and technological, as well as functional parameters.

Further research needs to allow infrastructural development of the postal units, as the basic business resource, and stimulate professional public in further study and development of the active planning model adaptable to the changes in the environment. 
Dr. sc. JOSIP GRACIN

E-mail: josip.gracin@posta.hr

Hrvatska pošta d. d.

Jurišićeva 13, 10000 Zagreb, Republika Hrvatska

Dr. sc. ANTUN STIPETIĆ

E-mail: stipetic@fpz.hr

Sveučilište u Zagrebu, Fakultet prometnih znanosti

Vukelićeva 4, 10000 Zagreb, Republika Hrvatska

\section{SAŽETAK}

\section{DIZAJNIRANJE JEDINICA POŠTANSKE MREŽE}

Postojeća poštanska infrastruktura ne može učinkovito podržavati zahtjeve novih tehnologija i ponudu usluga na otvorenom tržištu poštanskih usluga. Poštanski uredi ne zadovoljavaju novim potrebama, stoga je nužna prilagodba novim prometno - uslužnim zahtjevima. Provodilo se istraživanje funkcioniranja poštanskog sustava u Republici Hrvatskoj sa svrhom da se funkcionalna opremljenost sustava prilagodi uvođenju novih tehnologija i usluga. Istovremeno se postavio zahtjev javnom poštanskom operatoru za učinkovitije obavljanje univerzalne poštanske usluge. Temeljem provedenih analiza funkcioniranja poštanskog sustava predložen je modularni postupak dizajniranja jedinica poštanske mreže koji omogućava prilagodbu novim tehnološkim, organizacijskim i sigurnosnim zahtjevima, poštanskog sustava.

\section{KLJUČNE RIJEČI}

poštanske jedinice, dizajniranje modula, efikasnost poštanskog prometa

\section{LITERATURE}

[1] Akti Kongresa Svjetske poštanske Unije (World Post Union Congress Acts), Bucharest, HP, 2005

[2] Analiza tržišta poštanskih i kurirskih usluga u RH u 2006. g. (Market analysis of postal and courier services in Croatia in 2006), Vijeće za poštanske usluge (Council for Postal Services), Zagreb, September 2007

[3] CEPT: Poštanske studije (Collection D Etudes Postales), Bern, 1965-1990

[4] C. W. Churchman: Sistemski pristup (The System Approach) - translation, CDD, Zagreb, 1986

[5] Gracin, J.: Modeli funkcionalne infrastrukturne opremljenosti poštanskog sustava, Faculty of Transport and Traffic Sciences, Zagreb, 2007

[6] Neufert, E.: Arhitektonsko projektovanje, Građevinska knjiga, Beograd, 1978

[7] United States Postal Service Transformation Plan, 2002

[8] Wymore, A. W.: Model-based systems engineering, CRC Press, 1993

[9] Zakon o poštanskim uslugama (Postal Services Act), Official Gazette No. 88/09, Zagreb, 2009

[10] Ziegler, B. P.: Theory of Modelling and Simulation, John Wiley, New York, 1986 